Military Technical College Kobry Elkobbah, Cairo, Egypt.

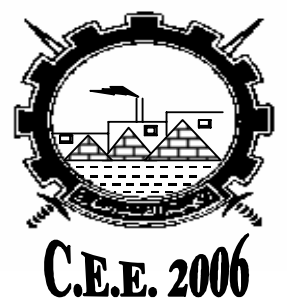

$3^{\text {rd }}$ International Conference

On

Chemical \& Environmental

Engineering

\title{
THIOLATE VS THIONE COORDINATION IN MODEL COMPLEXES OF ZINC (II) METALLPROTEINS
}

\author{
Ibrahim M. M. * and Shaban Sh. Y. *
}

\section{ABSTRACT}

We synthesized and characterized a new $S_{4}$-based zinc complex with thione $\left[T{ }^{x y l} Z n S T m^{x y l}\right] 2$ as sulfur-donor ligand. Structural determination by X-ray diffraction indicated that the coordination geometry around zinc atom is close to regular tetrahedral with $S-Z n(1)-S$ bond angles in the range $106-113^{\circ}$. The reactivity studies showed that complex 2 is much less susceptible to methylation than that of complex $\left[\mathrm{Tti}^{\mathrm{xy}} \mathrm{ZnSC}_{6} \mathrm{H}_{5}\right]$ 1, which contains thiolate as sulfur-donor ligand. This decrease in the nucleophilicity could be explained by electronic effects of thione versus thiolate.

\section{KEYWORDS}

Syntheses, Zinc(II) complexes, Repair protein, biomimetics, methylation.

\footnotetext{
* Faculty of Education, Tanta University.
} 


\section{INTRODUCTION}

All living organisms have developed complex systems to protect cells from the toxic effects of mutagenic chemicals and radiation. The regulation and function of DNA repair mechanisms have been characterized extensively in Escherichia coli. The E. coli Ada protein a key player in the adaptive response of bacteria to methylating agents, repairs methyl phosphotriesters in DNA by direct, irreversible transfer of the methyl group to one of its cysteines [1], Cys 69 (Scheme 1). This protein contains zinc(II) ion tightly bound to four cysteine residues, one of which is $\mathrm{Cys}_{69}$, the methyl acceptor. Alkylation on $\mathrm{Cys}_{69}$, showing that this particular cysteine ligand is electronically activated relative to the other three cysteines [2].

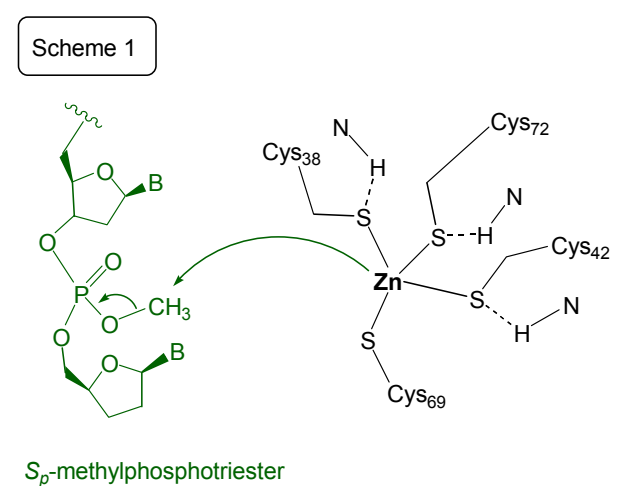

As part of our studies in biomimetic zinc chemistry [3] and in order to mimic the zinc(II) coordination structure as well as the function of the zinc(II) ion at the active site, several monomeric zinc(II) complexes have been designed and investigated to elucidate the detailed reaction mechanism in these thiolate-alkylating zinc metalloproteins [4].

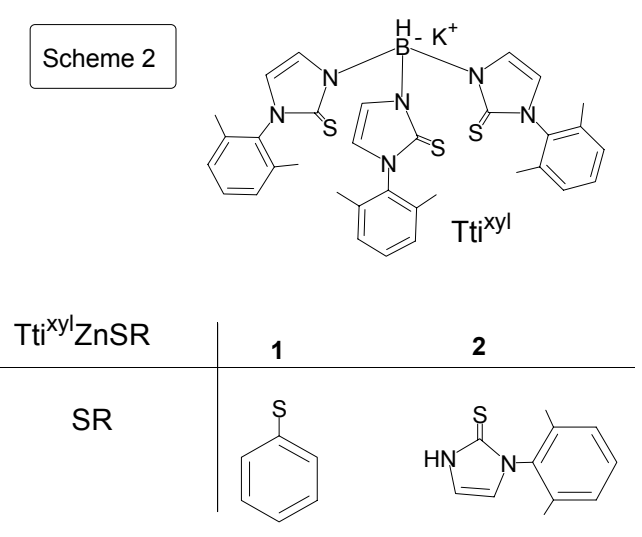

The ligand, potassium hydrotris tris(2-mercapto-1-xylylimidazole)borate, $\mathrm{Tti}^{\mathrm{xyl}}$ was used to emulate the $\left[S_{3}\right]$ coordination environment provided by the three cysteine amino acid residues in zinc proteins [5]. We report herein the design, synthesis, characterization and structural properties of a new $S_{4} Z n$ complex with thione $\left[\mathrm{Tti}^{\mathrm{xyl}} \mathrm{ZnSTm}{ }^{\mathrm{xy}}\right] 2$ as sulfur-donor ligand (scheme 2). Structural determination by X-ray diffraction indicated that the coordination geometry around zinc atom is close to regular tetrahedral with $S-Z n(1)-S$ bond angles in the range $106-113^{\circ}$. The reactivity studies showed that complex 2 is less susceptible to methylation than that of 
complex 1, which contains thiolate as sulfur-donor ligand [6-8]. This is decrease in the nucleophilicity could be explained by electronic effects of thione versus thiolate.

\section{EXPERIMENTAL SECTION}

Synthesis of the model complexes 1 and 2

The synthesis of the zinc model complexes 1 and 2, the experimental techniques and the standard IR and NMR equipment were described previously [6]. All other organic reagents were bought from Merck.

Kinetic measurements for the reaction of zinc(II) complexes 1 and 2 with $\mathrm{CH}_{3} \mathrm{I}$

All experiments were performed as previously reported [6-8] . In a typical experiment, $10 \mathrm{mM}$ of the thiolate complex was dissolved in $\mathrm{CDCl}_{3}$ followed by addition of $5-15$ equivalents of Mel. All the reactions were monitored by ${ }^{1} \mathrm{H}$ NMR spectroscopy at $300 \mathrm{~K}$. The ${ }^{1} \mathrm{H}$ NMR signals of the three thioimidazolyl protons of the reactant thiolate complexes 1 or 2 and the produced iodo complex 3 [5] were used as an integral standard. The increase in the intensity of the ethyl protons of the produced methylthioether were recorded and integrated relative to the standard thioimidazole protons.

\section{RESULTS AND DISCUSSION}

Characterization of the model complexes 1 and 2

The ligand $\mathrm{KTti}^{\mathrm{xyl}}$, coordinating through three thione sulphurs, mimics the three sulfur donors in the Ada protein. In each of these complexes, the fourth ligand (thione vs thiolate) as we showed in (Scheme 1) serves to represent homocysteine coordination to zinc in the protein. The ligand potassium hydrotris[N-(xylyl)-2-thioimidazolyl)borate $\mathrm{KTti}^{\mathrm{xyl}}$ and $\mathrm{zinc}(\mathrm{II})$ complex $\left[\mathrm{Tti}^{\mathrm{xy}} \mathrm{ZnSC}_{6} \mathrm{H}_{5}\right] 1$ were prepared according to published procedures [6]. Complex $\left[\mathrm{Tti}^{\mathrm{xyl}} \mathrm{ZnSTm}{ }^{\mathrm{xyl}}\right] \mathbf{2}$ was obtained by the reaction of the previously reported perchlorate complex [5], $\mathrm{Tti}^{\mathrm{xyl}} \mathrm{Zn}-\mathrm{OClO}_{3}$ with one equivalent of $\mathrm{N}$ (xylyl)-2-thioimidazole in anhydrous methanol. The complex was fully characterized by using ${ }^{1} \mathrm{H}$ NMR, FT-IR, elemental analysis, and X-ray crystallography. The ${ }^{1} \mathrm{H}$ NMR spectra of 2 showed different chemical environments of the thioimidazolyl methyl groups of the ligand system, $\mathrm{Tt}$, and the coligand.

\section{Crystal Structure determination:}

Complex 2 crystallizes as a monomer in monoclinic crystal system in the space group P2(1)/c. An ORTEP representation of the cationic part of the molecular structure of 2 is shown in figure 1 with selected bond lengths and angles contained in Table 1. The zinc atom, wih tetrahedral geometry, is coordinated by the sulfur atom of an HTim coligand and by three sulfur atoms of the tripodal ligand Tti, similar to the arrangement of $\left[\mathrm{Tti}^{\mathrm{Ph}}\right] \mathrm{Zn}\left(\mathrm{HTim}^{\mathrm{Ph}}\right)\left(\mathrm{ClO}_{4}\right)$ [9]. The $\mathrm{Zn}(1)-\mathrm{S}(4)$ bond lengths of 2.358(3) $\AA$ is significantly longer than that found in the thiolate complex $\left[\mathrm{Tti}^{\mathrm{xy}} \mathrm{ZnSC}_{6} \mathrm{H}_{5}\right] 1(\mathrm{Zn}(1)-\mathrm{S}(4) 2.248 \AA$. The average $\mathrm{S}-\mathrm{Zn}(1)-\mathrm{S}$ bond angles are essentially the same as those obtained in of $\left[\mathrm{Tti}^{\mathrm{Ph}}\right] \mathrm{Zn}\left(\mathrm{HTim}^{\mathrm{Ph}}\right)\left(\mathrm{ClO}_{4}\right)$ [9] and $\left[\mathrm{Cu}(\mathrm{Tim})_{3}\right]\left(\mathrm{NO}_{3}\right)$ [10] (average $109.3^{\circ}$ ). The coordination of the $\mathrm{Tim}^{\mathrm{xyl}}$ colligand to the $\left[\mathrm{Tti}^{\mathrm{xyl}}\right] \mathrm{Zn}$ cenetr is very similar to that of the analogous group of the ligand system, which indicate that the attachement of the three thioimidazolyl group to boron exerts very little perturbation on the ability of the thioimidazolyl coligand to bind to zinc. 


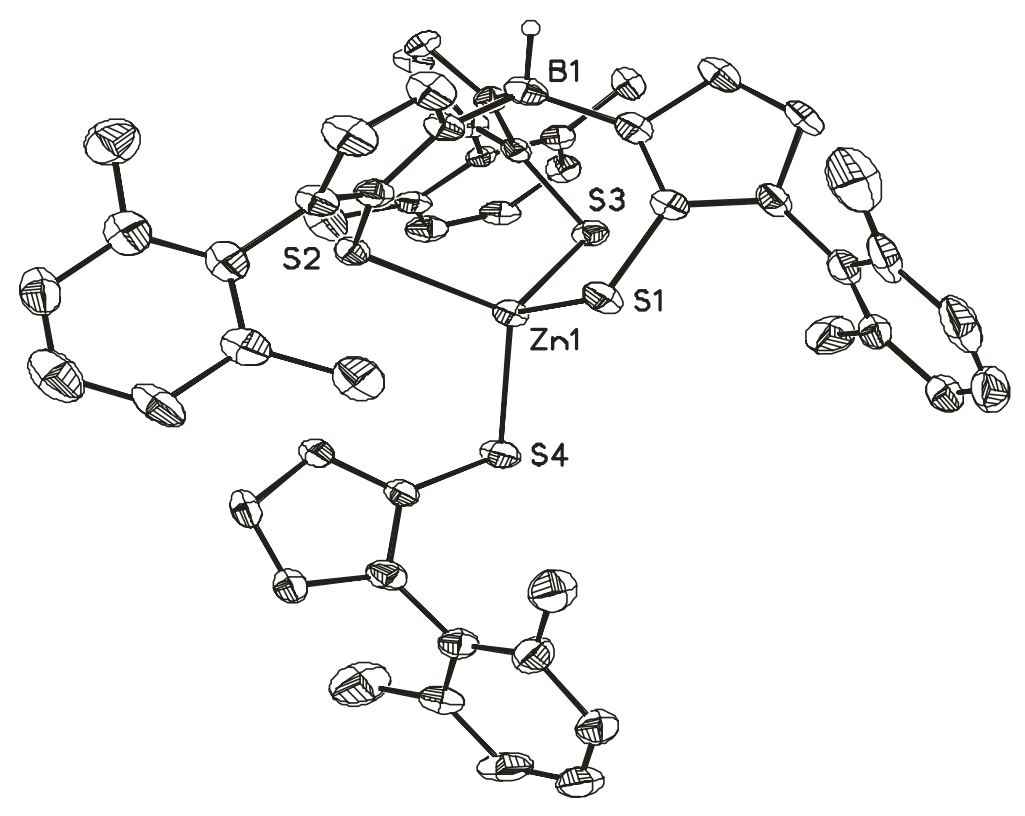

Fig. 1. ORTEP drawing of molecular structure of the actionic part $\left[\mathrm{Tti}^{\mathrm{xy}} \mathrm{ZnSTm}{ }^{\mathrm{xy}}\right]^{+} \mathbf{2}$. Ellipsoids are depicted at $30 \%$ probability level.

Table 1. Bond lengths $[\AA]]$ and angles $\left[{ }^{\circ}\right]$ of $\left[\mathrm{Tti}^{\mathrm{xy}} \mathrm{ZnSTm}{ }^{\mathrm{xy}}\right] 2$

\begin{tabular}{lll}
\hline Bond length $[\AA]$ & $\mathrm{Zn}(1)-\mathrm{S}(1)$ & $2.341(2)$ \\
\hline $\mathrm{Zn}(1)-\mathrm{S}(3)$ & $2.351(2)$ \\
$\mathrm{Zn}(1)-\mathrm{S}(4)$ & $2.358(3)$ \\
$\mathrm{Zn}(1)-\mathrm{S}(2)$ & $2.363(2)$ \\
& & \\
${\left.\text { Bond angles }{ }^{\circ}\right]}^{\mathrm{S}(1)-\mathrm{Zn}(1)-\mathrm{S}(3)}$ & $106.23(9)$ \\
$\mathrm{S}(1)-\mathrm{Zn}(1)-\mathrm{S}(4)$ & $108.93(9)$ \\
$\mathrm{S}(3)-\mathrm{Zn}(1)-\mathrm{S}(4)$ & $115.25(9)$ \\
$\mathrm{S}(1)-\mathrm{Zn}(1)-\mathrm{S}(2)$ & $106.70(9)$ \\
& $\mathrm{S}(3)-\mathrm{Zn}(1)-\mathrm{S}(2)$ & $106.57(8)$ \\
\hline & $\mathrm{S}(4)-\mathrm{Zn}(1)-\mathrm{S}(2)$ & $112.65(9)$ \\
\hline
\end{tabular}

\section{Kinetik investigation for the methylation reactions}

Reactions of 1 and 2 with $\mathrm{CH}_{3} \mathrm{l}$ in deuterated chloroform results in the quantitative formation of methylthioethers and $\mathrm{Tti}^{\mathrm{xyl}} \mathrm{Zn}$ (II)-bound iodide complex $\mathbf{3}$ as indicated in equation 1 . The pseudo-first-order constants $\mathrm{k}_{\mathrm{obs}}$ were calculated.

$$
\mathrm{Tti}^{\mathrm{xyl}} \mathrm{Zn}-\mathrm{SR}+\mathrm{CH}_{3} \mathrm{I} \longrightarrow \underset{3}{\mathrm{Tti}^{\mathrm{xyI}} \mathrm{Zn}-\mathrm{I}}+\mathrm{RSCH}_{3}
$$

The

methyaltion reactions were followed in ${ }^{1} \mathrm{H}-\mathrm{NMR}$ at $300 \mathrm{~K}$ by monitoring the decrease 
and increase in the intensities of the methyl resonances of the consumed 1 or 2 and the produced methyl ethyl thioether. The proton chemical shifts of the resulting $\mathrm{CH}_{3} \mathrm{SC}_{6} \mathrm{H}_{5}$ and $\mathrm{CH}_{3} \mathrm{STm}^{\mathrm{xyl}}$ are identical to those of a genuine sample, indicating that the thioether product is not coordinated to zinc. A typical ${ }^{1} \mathrm{H}$ - NMR spectra for the methylation reaction of complex 1 as a function of time is shown in Figure 2. The log plots for five different concentrations of $\mathrm{CH}_{3} \mathrm{I}$ are linear with correlation coefficients > 0.995. the resulting $k_{\text {obs }}$ values, plotted against the $\mathrm{CH}_{3}$ l concentration, define a regression line which passes through the origin with correlation coefficient of 0.985 . the second order rate constant, obtained according to $k_{\mathrm{obs}}=\mathrm{k}^{\prime}\left[\mathrm{CH}_{3} \mathrm{l}\right]$, resulted as = $0.10 \mathrm{M}^{-1} \mathrm{~s}^{-1}$ for complex 1 . Whereas the kinetic reaction was too slow to follow in the case of complex $\mathbf{2}$ under the same reaction conditions. The clean second order reaction and the occurrence of the alkylations in completely non polar media, i.e., lack of salvation of intermediate anionic species are good arguments in favour of the intramolecular nature of the alkylation process $\left[\mathrm{CH}_{3} \mathrm{l}\right]$.

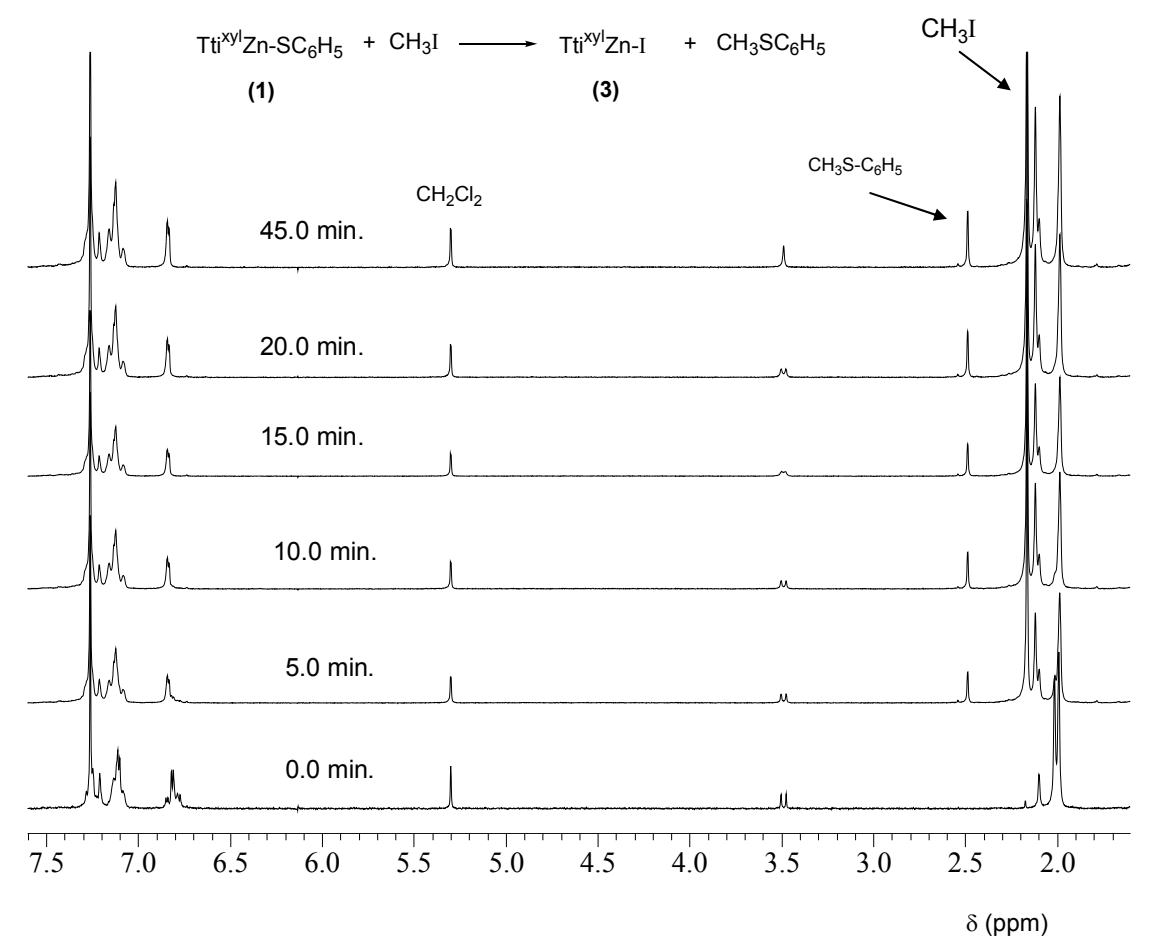

Fig. 2. Time dependent ${ }^{1} \mathrm{H}$ NMR spectra for the reaction between $\mathrm{Tt}^{\mathrm{xyl}} \mathrm{Zn}-\mathrm{S} \mathrm{C}_{6} \mathrm{H}_{5} 1$ $(10 \mathrm{mM})$ and $\mathrm{CH}_{3} \mathrm{l}(50 \mathrm{mM})$ in $\mathrm{CDCl}_{3}$ at $300 \mathrm{~K}$ under pseudo-first-order conditions.

The rate constant observed for the thiolate methylation in $\mathbf{1}$ is much higher than that the thione coligand in 2 under the same conditions [8], it provides a means to determine whether the inertness of the sulfur atoms of the $\mathrm{Tti}^{\mathrm{xyl}}$ ligand of $\mathbf{1}$ is associated with the constraints imposed by attachement to the boron center. It is therefore, notable that whereas 1 reacts immediately with methyl iodide to give $\mathbf{3}$, the corresponding reaction of $\mathbf{2}$ occurs over a period of days. This results indicate that the corrdinated thione $\mathrm{Tm}^{\mathrm{xyl}}$ ligand is leass susceptible to electrophilic attack than the thiolate ligand, presumably a reflection of the thione versus thiolate nature of the sulfur atom [11]. 


\section{CONCLUSION}

The preparation and characterization of this particular family of thioimidazolylborate zinc complexes Tti ${ }^{\mathrm{xy}} \mathrm{ZnSR} \mathbf{1}, 2$ (where $\mathrm{R}=\mathrm{C}_{6} \mathrm{H}_{5}$ and $\mathrm{HTm}^{\mathrm{xyl} \text {, }}$ respectively) has enabled us to evaluate how the nature of thiolate coligand affect the methyl transfer reaction. The driving force for the methylation reactions lies in the high nucleophilicity of $T \mathrm{TtiZn}^{\mathrm{xyl}}$-bound thiolate in $\mathbf{1}$ than that of bound thione in $\mathbf{2}$. and the low donor qualities of the resulting thioethers. This decrease in the nucleophilicity could be explained by electronic effects of thione versus thiolate.

\section{ACKNOWLEDGMENTS}

The authors gratefully acknowledge Professor Heinrich Vahrenkamp for his valuable discussions during this work. I am indebted to Drs. Deck, H. Brombacher, and G. Steinfeld for their assistance with the X-ray structure determinations.

\section{REFERENCES}

[1] J. Habazettl, L. C. Myers, F. Yuan, G. L. Verdine, G. Wagner, Biochemistry 35 (1996) 9335.

[2] D. Swenson, N. C. Baenziger, D, Coucouvanis, J. Am. Chem. Soc. 100 (1978) 1932.

[3] (a) K. Ichikawa, K. Nakata, M. M. Ibrahim, and S. Kawabata Advances in Chemical Conversations for Mitigating Carbon Dioxide Studies in Surface Science and Catalysis, 114, 309 (1998); (b) K. Ichikawa, K. Nakata, and M. M. Ibrahim, Chem. Lett. 2000, 796; (c) M. M. Ibrahim, N. Shimomura, K. Ichikawa, M. Shiro, Inorg. chim. Acta, 2001, 313, 125-136; (d) M. M. Ibrahim, K. Ichikawa, M. Shiro, Inorg. chim. Acta, 2003, 353, 187-196, (e) M. M. Ibrahim, K. Ichikawa, M. Shiro, Inorg. chem. Commun., 2003, 6, 1030-1034, (f) T. Echizen, M. M. Ibrahim, K. Nakata, M. Izumi, K. Ichikawa, M. Shiro, J. Inorg. Biochem., 2004, 98, 1347-1360.

[4] (a) S. J. Chiou, J. Innocent, C. G. Riordan, K. C. Lam, L. Liable-Sands, A. L. Rheingold. Inorg. Chem. 39 (2000) 4347; (b) B. M. Bridgewater, T. Fillebeen, R. A. Friesner, G. Parkin, J. Am. Chem. Soc., Dalton Trans. (2000) 4494; (c) B. S. Hammes, C. J. Crrano. Chem. Commun. (2000) 1635; (d) B. M. Bridgewater, T. Fillebeen, R. A. Friesner, G. Parkin, Chem. Soc., Dalton Trans. (2000) 4494; (e) C. R. Warthen, B. S. Hammes, C. J. Carrano, D. C. Crans, J. Biol. Inorg. Chem. 6 (2001) 82; (f) B. S. Hammes, C. J. Crrano, Inorg. Chem. 40 (2001) 919; (g) U. Brand, M. Rombach, J. Seebacher, H. Vahrenkamp, Inorg. Chem. 40 (2001) 6151; (h) M. Ji, B. Benkmil, H. Vahrenkamp, Inorg. Chem. 44 (2005) 3518; (i) M. M. Morlok, K. E. Janak, G. Zhu, D. A. Quarless, G. Parkin, J. Am. Chem. Soc. 127 (2005) 14039.

[5] M. M. Ibrahim, M. Shu, H. Vahrenkamp, Eur. J. Inorg. Chem. (2005) 1388.

[6] M. M. Ibrahim, J. Seebacher, G. Steinfeld, H. Vahrenkamp, Inorg. Chem. 44 (2005) 8531.

[7] M. M. Ibrahim, G. He, J. Seebacher, B. Benkmil, H. Vahrenkamp, Eur. J. Inorg. Chem. (2005) 4070.

[8] U. Brand, J. Seebacher, M. Shu, M. Ji, M. M. Ibrahim and B. Benkmil, Inorg. Chem. submitted. 
[9] (a) A. Docrat, M. M. Morlok, B. M. Bridgewater, D. G. Churchill, G. Parkin, Polyhedron 23 (2004) 481; (b) M. M. Morlok, A. Docrat, K. E. Janak, J. M. Tanski, G. Parkin, J. Chem. Soc., Dalton Trans. (2004) 3448.

[10] E. S. Raper, Inorg. Chim. Acta, 98 (1985)35.

[11] S. Laufer, G. Wagner, D. Kotschenreuther, Angew. Chem. Int. Ed. Engl. 41 (2002) 2290. 